\title{
COMPETENCY REQUIREMENTS FOR FIRST-LINE MANAGERS TO DEAL WITH RESISTANCE TO CHANGE
}

\author{
CN LOMBARD \\ A CRAFFORD \\ Leadership in Performance and Change Programme \\ Department of Human Resource Management \\ Rand Afrikaans University
}

\begin{abstract}
Continuous changes in the needs of markets require effective change management at all levels in organisations. First-line managers are directly responsible for meeting the demands of clients and resistance to change at this level could result in sub-standard outputs. The effectiveness of change interventions will be largely determined by the competence of first-line managers to facilitate the desired change taking into account resistance to change. The purpose of this article is to identify competencies required by first-line managers to deal with resistance to change. The findings are based on a literature study and functional analysis.
\end{abstract}

\section{OPSOMMING}

Kontinue verandering in die behoeftes van markte vereis effektiewe bestuur van verandering in alle vlakke van organisasies. Eerstelyn bestuurders is direk verantwoordelik daarvoor om aan verwagtinge van kliënte te voldoen, want weerstand teen verandering op hierdie vlak kan tot sub-standaard uitsette aanleiding gee. Die effektiwiteit van veranderingsintervensies in organisasies sal grootliks afhang van die bevoegdheid van eerstelyn bestuurders om die verwagte verandering te weeg te bring met in agneming van weerstand teen verandering. Die doel van hierdie artikel is om bevoegdhede te identifiseer wat eerstelyn bestuurders sal benodig om weerstand te kan hanteer. Die bevindinge is gebaseer op 'n literatuur studie en funksionele analise.

The establishment and maintenance of organisational effectiveness has, in contemporary management science, become more complex and dynamic (Zeffane, 1996; Hudson, 1999; French \& Delahaye, 1996; Weber \& Weber; 2001, Kinnear \& Roodt, 1998; Appelbaum, St-Pierre \& Glavas, 1998). The complexity emerges from greater interdependence among world economies, while the dynamism is a direct result of the information age as well as the global arena organisations operate in. The complex, dynamic and competitive nature of business requires that organisations cannot remain stable for long as constant change external to organisations require constant change within. In fact, it is argued, that organisations are only as successful as their efforts to respond to changes in the environment and adapt accordingly. This requires effective change management at all levels in the organisation, but nowhere is this more important than at the interface with customers and clients. For change efforts to be regarded as truly successful, one cannot only measure how effective the change strategy is or how well it is led, but rather the extent to which the change efforts have led to improved service delivery and increased client satisfaction (Appelbaum et al, 1998; Moran \& Brightman, 2001).

A critical factor in the provision of excellent service delivery is the first-line manager, as their influence and responsibility extends to operative employees - those people responsible for ensuring high quality service and products. The effectiveness of change interventions in organisations will thus largely be determined by the competence of first-line managers to facilitate the desired change through and with operative employees (Moran \& Brightman, 2001). This view is supported by Katzenbach (in Appelbaum et al; 1998) who stresses that the most difficult aspect of change efforts lies in changing people and their skills, knowledge and behaviour. This is particularly challenging given the natural tendency of people to resist change. Most people are suspicious about the unfamiliar; and are naturally concerned about how to get from the old to the new, especially if it involves learning something new and risking failure (De Jager, 2001). The danger however lies in the fact that resistance to change, particularly at operative levels

Requests for copies should be addressed to: CN Lombard, Department of Human Resource Management, RAU University, PO Box 524, Auckland Park, 2006 manifests in the delivery of sub-standard outputs, which can drive customers to the competition. It is thus crucial that firstline managers should be able to deal with resistance to change in an effective manner. Given the importance of first-line managers and their capacity to manage resistance to change, the focus of this paper is on the identification of competencies required by first-line managers to effectively manage resistance to change. To derive these competencies, it will be necessary to discuss the concept of resistance to change in greater detail as well as consider the requirements for successful change, as these pertain to first-line managers.

\section{RESISTANCE TO CHANGE}

Resistance refers to any opposition to a shift in the status quo In physical terms, resistance means "to slow a process down" or to "put obstacles in the way of goal achievement" (Mariotti, 1998, p.140). Resistance to change thus refers to an expression of reservation that arises as a response or reaction to change (Mabin, Forgeson \& Green, 2001). This response is viewed as natural as change involves unlearning habitual patterns and learning new ways of thinking and feeling which result in new behaviours (Claxton, 1999; Gratton, 2001). This process is obviously anxiety provoking and hence the resistance (Kets de Vries, 2002). Two terms closely associated with describing resistance to change, are "fear of loss" and "fear of the new" (Coker, 2000, p. 24). The aspect of loss is particularly pertinent and the following factors may contribute to a fear of loss (Coker, 2000; Mabin et al, 2001; Kets de Vries, 2002; Seely, 2000; Pheng, 1999):

- Individual factors (personality factors such as a high need for control, locus of control, need for achievement, etc.; attitudes based on previous experiences of change)

- Economic loss (loss of job, reduction in earnings or less opportunity for economic growth)

- Inconvenience (more work for the same pay, more effort for the same output, greater responsibility and no additional rewards)

- Threats (increased insecurity, anxiety or worry)

- Power (loss of control and having inferior knowledge or levels of competence) 
- Social disruption (group cohesiveness; reduced contact with trusted friends or family)

- Losing face (the fear of appearing foolish in the face of new demands)

Resistance to change can furthermore be distinguished at three different levels (Mariotti; 1998, Maurer, 2000). Level 1 resistance is based on a lack of information or on honest disagreement over the facts. Level 2 entails personal and emotional resistance and manifests because people are afraid that change may cost them their jobs, reduce their control, or cause them to lose face. Finally, level 3 is associated with employee's managers or what these managers represent. In these situations, people will resist almost any changes that are suggested to them, as they link "change" and "management" with one another.

\section{Managing resistance to change}

There are two crucial aspects that underlie the successful management of resistance to change. Both an understanding of individuals and the differences that exist between employees together with knowledge of the behaviour underlying the resistance to change are required.

George and Jones (2001) stressed that change efforts should be focussed on an individual level as change is initiated and implemented by individuals, despite organisations being collective entities. Managers interested in successfully managing change must learn how to encourage individuality, and need to legitimate, respect, and value diverse individual experiences (Steiner, 2001). This includes being aware of the abilities and strengths of each individual and the capacity to capitalise on these in the context of work team. First-line managers should be able to support employees on an individual basis to deal with the envisaged change (Kets de Vries, 2002). Dealing with the concerns of employees will help identify the reasons for resistance and enable managers to deal with these proactively (Bechtel \& Squires, 2001; Coker, 2000). Ignoring people issues can lead to failure in achieving successful change (Bechtel \& Squires, 2001; Folger \& Skarlicki, 1999). In managing resistance to change, first-line managers may also be required to deal with resistant behaviour in the team context, for example group decision-making sessions (George \& Jones, 2001; Mabin et al, 2001).

The first-line manager should also have a basic understanding of what underlies and influences employee behaviour in the context of change. It is recognised that human behaviour is complex and the factors influencing it, extensive. Nevertheless, it is necessary that the first-line manager be aware of the factors influencing behaviour and learning, as a basis for managing the change process. As stated, change involves learning new ways of thinking and feeling, which result in new behaviours. The relationship between these factors in behaviour and learning is complex and an in-depth analysis is beyond the scope of this article. For this reason, the assumption is made that emotions and cognition interact and mutually influence each other and result in behaviour. (Kets de Vries, 2002; Kotter \& Cohen, 2002). A brief discussion of each of these factors and their role in the change process follows.

Cognition is shaped by perceptions as individuals filter and selectively process information from their environments. In this way, people choose from available information that which they would like to believe and may ignore information that challenges the world as they wish to perceive it. An important aspect with regard to change is the degree to which employees perceive the organisation to be ready for change. Defined as "the cognitive precursor to the behaviours of either resistance to, or support for, a change effort", these perceptions can facilitate or undermine the effectiveness of a change intervention (Eby, Adams, Russel \& Gaby, 2000, p. 419). Employees respond to what is happening in their environment and based on their perceptions, make assumptions about the change process. These may be accurate or inaccurate but will influence whether change is resisted or not. For this reason, understanding employees' perceptions regarding the readiness for change is necessary in dealing with resistance to change.

Emotions are relatively intense affective states that interrupt ongoing thought processes and behaviours. They arise when discrepancies are encountered that are relevant to one's personal well-being or goals and objectives. Emotions are thus functional and adaptive in that they provide signals of situations that are personally relevant and in need of attention. Emotions are triggered by thought processes, which in turn motivate cognitive activity and behaviour to deal with the emotion-triggering situation (Goleman, 1996; George \& Jones, 2001). Behaviour that manifests itself as resistance to change is thus not only based on what people think, but the feelings they experience during the change process (Kotter \& Cohen, 2002).

The afore-mentioned discussion suggests that first-line managers should guide the individual through a cognitive process to ensure an understanding of what the change entails and the impact thereof on the individual. This impact should be defined in terms what the person will need to let go of, what competencies will be required to be effective in the new environment, and what support will be needed to achieve personal success. In addition, the individual must be supported on an emotional level as they confront natural feelings of fear and loss.

\section{SUCCESSFUL CHANGE}

In addition to understanding resistance to change, it is also necessary to identify characteristics of successful change efforts as these provide further guidelines in the successful management of resistance to change.

Successful change can be described as the flexibility that organisations show to be able to proactively respond to changes in the market or external environment (Appelbaum et al, 1998). The following characteristics are regarded as crucial in successful change efforts.

\section{Overcoming managerial resistance to change}

The misconception exists that managers do not resist change and that resistance only comes from operative employees. Van Buren and Werner (in Appelbaum et al, 1998) stated that the resistance of middle and first-line managers is often identified as a major implementation barrier. These managers are afraid of losing their jobs and are threatened because of pressure applied by senior management to redefine their roles from primarily directing to coaching and counselling. It is however crucial that managers are willing, able, allowed and supported in dealing with change first before they attempt to facilitate change in the lower levels of the organisation. First-line managers should have a comprehensive understanding of the envisaged change and not allow their own fears to influence the way they communicate change to their areas of responsibility. In doing so, they take personal responsibility for change in their areas of responsibility and influence.

\section{Business case for change}

Once the triggers for change have been identified, successful change is characterised by a strong business case for the proposed change. In this instance it is important for managers to be able to see the bigger organisational picture to be able determine which success criteria will be most important for their area of responsibility and influence. Supporting the business case for change should be the strategic direction of the organisation in the form of a vision and mission (Clarke \& Meldrum, 1999; Mabin et al, 2001; Bechtel \& Squires, 2001; Corporate Executive Board, 2001c). Although senior 
management develops the organisational business case, first-line managers should be able to cascade change strategies to their areas of responsibility and derive a business case for their area of influence. This should encourage first-line managers to take ownership of the envisaged change.

In addition, the first-line managers should also be able to encourage change from the bottom up, as successful change efforts need not always be top-down (Zeffane, 1998). Organisations would benefit from first-line managers that are able to identify potential areas of change through and with their teams that can improve the product or service delivery of the organisation.

\section{Focus on the customer}

Organisations that facilitate effective change manage to focus on customers and their needs. They invest in ways to improve sales, provide superior service to clients, and they do not forget that their customers and their needs underlie the organisation's existence (Appelbaum et al, 1998). First-line managers should continuously strive to address the following seven questions in their operational areas of responsibility (Rampersad, 2001)

- Who are my customers?

- What do they need?

- What is my product or service?

- What are my customers' expectations and measures?

- Does my product or service meet their expectations?

- What is the process for providing my product or service?

- What action is required to improve my process?

By addressing these questions the first-line manager can identify opportunities for change and increasing the economic value of products and services. It can also serve as impetus for first-line managers to formulate a business case for change at their level.

\section{Effective communication}

A strong business case for change without an effective communication strategy will result in haphazard change efforts (Buckingham \& Coffman, 2001; Mabin et al, 2001; Bechtel \& Squires, 2001; Corporate Executive Board, 2001b; Seely, 2000; Zeffane, 1996). The communication strategy should include information on what will happen, when it will happen, and how it will happen. By describing step-by-step what will take place, management will be more apt to gain support from others and reduce resistance. Because change is most effectively facilitated one person at a time (Corporate Executive Board, 2001b; Buckingham \& Coffman, 2001; Zeffane, 1996) communication should be cascaded through the organisation to various levels and areas of responsibility. The goal is to ensure that all people receive the communication and to facilitate a process of change, one person at a time (Appelbaum et al, 1998; Seely, 2000). Furthermore, managers need to listen to the views, protests and problems of subordinates who are likely to understand the implications of the changes in their areas of influence.

To ensure effective communication, managers should communicate what they know, and assure employees that they will never be intentionally deceived. Managers can offer to answer questions and explain why some questions cannot be answered, as the information may not be available (Lewis, 1998; Kotter, 1996; Kotter \& Cohen, 2002). This implies that first-line managers should be empowered to answer questions on a needs basis and only do so once they fully understand the process.

\section{Leadership}

In a study conducted by the Corporate Executive Board (2001a) it was evident that the leadership competencies of relevant people should be at higher than acceptable levels before any attempt to change is made. Though the leadership does not always initiate successful change, it should be owned and driven by them (Walker, 1999; Kotter \& Cohen, 2002). Leadership during times of change requires courage as the leader may be required to do the following (Burdett, 1999):

- Stand alone

- Take tough decisions

- Say "no"

- Stand up against unnecessary bureaucracy

- Admit to making mistakes

- Admit that he of she is part of or the source of the problem

- Overcome fears of making mistakes

- Lead from the presumption of truth

The first-line manager should demonstrate an ability to lead their teams towards goal achievement. In doing so, they will have to live their personal visions of the change and lead their teams through effective communication, motivation and influence.

\section{People development}

The next requirement, individual and team development, is often neglected by organisations in attempting to implement successful change (Bechtel \& Squires, 2001; Corporate Executive Board, 2001a; Kotter \& Cohen, 2002; Seely, 2000). Change efforts require from individuals new skills and competencies, which can only be developed if the necessary ability, motivation and selfesteem are present. Where the challenges posed by the proposed change appear to outweigh the capacity of individuals to develop, resistance to change is likely to occur. For this reason, the first-line manager must be able to identify and facilitate the development of the requisite skills in the individuals in their team. This should be done on an individual basis, in conjunction with each team member, and should result in a development plan of action that will clearly indicate the commitment of the organisation and the individual to ensure competence.

\section{Structured implementation of change}

Another requirement for successful change is the application of structured approaches to change implementation. The most effective methods typically integrate attention to human issues (commitment, resistance, follow-through, etc.) with attention to the technical issues usually incorporated into project management methods (Hoopes \& Hale, 1999; Seely, 2000). This will require managers to have both excellent human relations and project management skills. They will require a clear understanding of the change supported by project management competencies to implement the change. They will also need to make time allocations for attending to the human issues involved and ensure that all the people dimensions are addressed.

\section{Effective monitoring and control}

Hoopes and Hale (1999) identified the necessity for monitoring and evaluation as a key principle in successful change, to ensure a results-based focus. The aim is to determine the payoffs achieved from the initiative and to learn valuable lessons about implementation that can be used to strengthen future changes. The goal of effective monitoring and control is to develop desirable behaviour and overcome those behaviours that may jeopardise change efforts. The first-line manager is responsible for coaching employees in this regard. Crucial in monitoring and control is the perception of fairness as in creating a fair workplace, resistance can be limited (Lewis, 1998).

\section{Structure to support strategy achievement}

Successful change in organisations requires structures that meet the needs of the organisational strategic direction. Appelbaum et al (2000), and the Corporate Executive Board (2001a) found that the involvement of employees in determining appropriate structures to facilitate change leads to effective structures that work. This will require first-line managers to design a team that will effectively facilitate change and allocate resources within their area of influence. First-line managers may also advise decision-makers regarding more appropriate organisational structures from their experience of successful change. 
Mutually agreed performance goals

Managers in successful companies improve performance by achieving agreement or consensus with employees in setting mutually agreeable performance goals. Employee suggestions are actively sought and a positive work-group spirit, serves as a basis for enhanced motivation (Appelbaum, et al, 1998; Seely, 2000). Such an approach can also secure ownership for performance goals as it comes from within and is not simply forced from the top. This will require of first-line managers to facilitate group decision-making and problem solving sessions to ensure optimal input and buy-in from team members.

\section{DEDUCTION OF COMPETENCIES}

Competence is defined as the skills, knowledge, attitudes, attributes and values required in performing a task and the ability to apply them in the work environment (Lindsay \& Stuart, 1997; Garavan, Barnicle \& O'Suilleabhain, 1999). For the purpose of the study, competence was viewed based on the framework outlined in Figure 1.

The deduction of competencies was based on the work of Fletcher (1997) and the National Examination Board for Supervisors and Management (1998). Fletcher (1997) is of the opinion that a functional approach reflects a broader concept of competence. This implies a focus on tasks as well as the way these are organised in the work role and management contingencies. Competence-based standards for effective performance are derived through a process of functional analysis. This is a top-down analytical approach of what the target group of employees should be able to do in the work environment and begins with the key purpose of the designated position in an organisation. In the context of this study, the key purpose of first-line managers is to deal with resistance to change. Analysis of the key purpose should result in the identification of key work roles, which are derived from the key purpose. Key roles are determined by asking the question: 'what has to happen for the key purpose to be fulfilled?" (National Examining Board for Supervisors and Management (NEBS \& M), 1998, p. 8). This approach will support a clear focus on the roles that should be performed rather than only the "the job" (Fletcher, 1997).

To formulate the competencies listed in Tables 1 to 14 , it was necessary to consider the theory of resistance to change and the management thereof as well as the requirements for successful change. The functional analysis of the information from the literature study resulted in the identification of key roles that first-line managers will perform to manage resistance to change effectively.

Fletcher (1997) suggests that the analytical process continues until "units of competence" are identified. These are described as activities that can be undertaken by one individual that have real meaning in the workplace (Fletcher, 1997; NEBS \& M, 1998). Each key role was analysed to determine the units of competence that comprise of specific work activities that are grouped together with other related work activities. To define units of competence, the question "What has to happen for this key role to be achieved?" was asked.

The next step in the functional analysis process is the identification of "elements of competence". Elements of competence can be described as detailed steps or descriptions of performance expected to ensure the delivery of a unit of competence (NEBS \& M, 1998). These are broad steps that can be followed to ensure the achievement of the related unit of competence. Stated differently, elements of competence are the things that responsible people should be able to do in the workplace in order to complete functions. In the functional analysis the question is asked: "What has to happen for the unit of competence to be achieved?"

To derive the competencies from the elements of competence, a functional analysis was conducted within the framework of a business process to determine the specific inputs required to be successful in the work environment. These inputs are the skills, knowledge, and behaviour (attitudes, attributes and values) that will have to be applied in the work environment to effectively deal with resistance to change. These inputs are, however, not sufficient, as there are organisation specific control guidelines (policies, procedures, rules, legislation, etc) that govern the performance of employees in organisations. There are also tools and equipment that the person should be able to use in the workplace that may be specific to the organisation. Of importance is that all applications of the required competencies take place within organisation-specific conditions and circumstances and that no two organisations are the same in this regard.

It is evident that the term first-line manager can be used to describe a broad spectrum of people. For the purpose of this paper the term is used to denote those people assigned with a

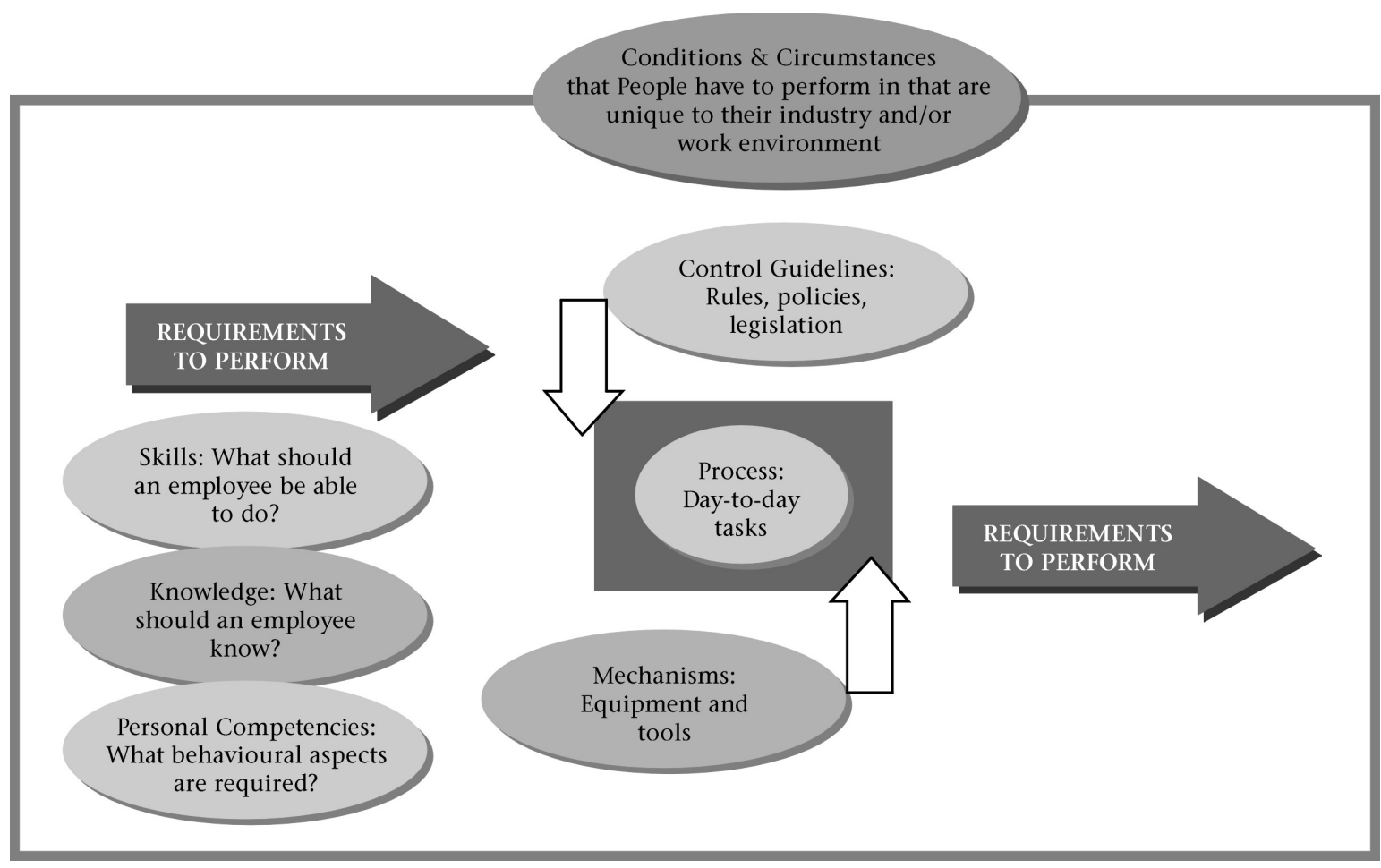

Figure1 Competency framework (Chris Lombard, 2002) 
managerial title and responsibility. The competencies listed will apply to people in this group, but may vary depending on the complexity and diversity of their specific tasks.

\section{Outcome of the Functional Analysis}

During the functional analysis process the following four key roles were identified:

- Align the change strategy of the area of responsibility with that of the organisation.

- Ensure personal readiness for change.

- Minimise resistance to change.

- Act as a continual catalyst for change.

Although the four key roles are not in a particular sequence, the second key role (Ensure personal readiness for change) should precede the third key role (Minimise resistance to change) as one can only manage change in others when one is prepared oneself.

It should also be noted that the manifestation of the last key role in organisations would be ideal for any organisation, as this implies that first-line managers and their teams take ownership for continuous improvement of systems and processes to the benefit of customers and clients.

In the discussion that follows each key role is highlighted and the units of competence are given. A breakdown of each unit of competence is provided in the tables following each paragraph.

The first key role first-line managers should perform is to align the change strategy of their areas of responsibility with that of the organisation. The units of competence that comprise the first key are listed below. The first-line manager should:

- Obtain a comprehensive understanding of the target state of the envisaged change.

- Obtain an understanding of customer needs/potential target market.

- Conduct a strategic plan for personal area of responsibility

- Facilitate planning to determine best-practice solutions

These are reflected in Tables $1-4$.

TABLE 1

COMPETENCIES TO OBTAIN A COMPREHENSIVE UNDERSTANDING OF CHANGE

Key role: Align change strategy of area of responsibility with that of the organisation

Unit of competence: Obtain a comprehensive understanding of the target state of change

Elements of competence Competencies

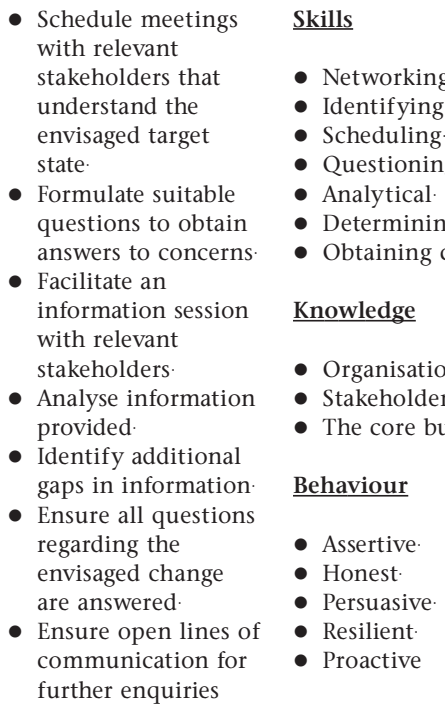

Control guidelines

- Organisational communication policy

Conditions and circumstances

- Deal with senior decision-makers

- Deal with diverse people

- Deal with stakeholders that may not interested in sharing information

TABLE 2

COMPETENCIES TO OBTAIN AN UNDERSTANDING OF CUSTOMER NEEDS/POTENTIAL TARGETS

Key role: Align change strategy of area of responsibility with that of the organisation

Unit of competence: Obtain an understanding of customer needs/potential target market

Elements of competence Competencies

- Formulate own understanding of changes in customer target market needs

- Formulate questions regarding your understanding of the change in customer needs.

- Identify stakeholders that can provide solutions to concerns

- Schedule meetings with informed stakeholders

- Clarify personal understanding of the envisaged changes

- Obtain requirements and suggestions from stakeholders

- Document findings

$\underline{\text { Skills }}$

- Analytical

- Questioning

- Networking

- Scheduling.

- Business writing

- Information processing

- Communication

Knowledge

- Customer needs and requirements

- Core business processes

Behaviour

- Assertive.

- Professional

- Persuasive

- Attention to detail

- Resilient

Control guidelines

- Prescribed company policies and procedures stipulating behaviour when dealing with stakeholders

\section{Conditions and circumstances}

- Dealing with people external to the organisation

- Dealing with senior decision-makers

- Dealing with diverse people

- Dealing with demanding people

TABLE 3

COMPETENCIES TO CONDUCT A STRATEgic PLAN FOR PERSONAL AREA OF RESPONSIBILITY

Key role: Align change strategy of area of responsibility with that of the organisation

Unit of competence: Conduct a strategic plan for personal area of responsibility

Elements of competence

Competencies

- Ensure a

comprehensive

understanding of

intended

organisational

change

- Ensure a.

comprehensive

understanding of

impact of change $\underline{\text { Skills }}$

- Analytica

- Conducting a strategic analysis

- Goal/objective formulation

- Resource allocation

- Networking

- Determining trends and tendencies 


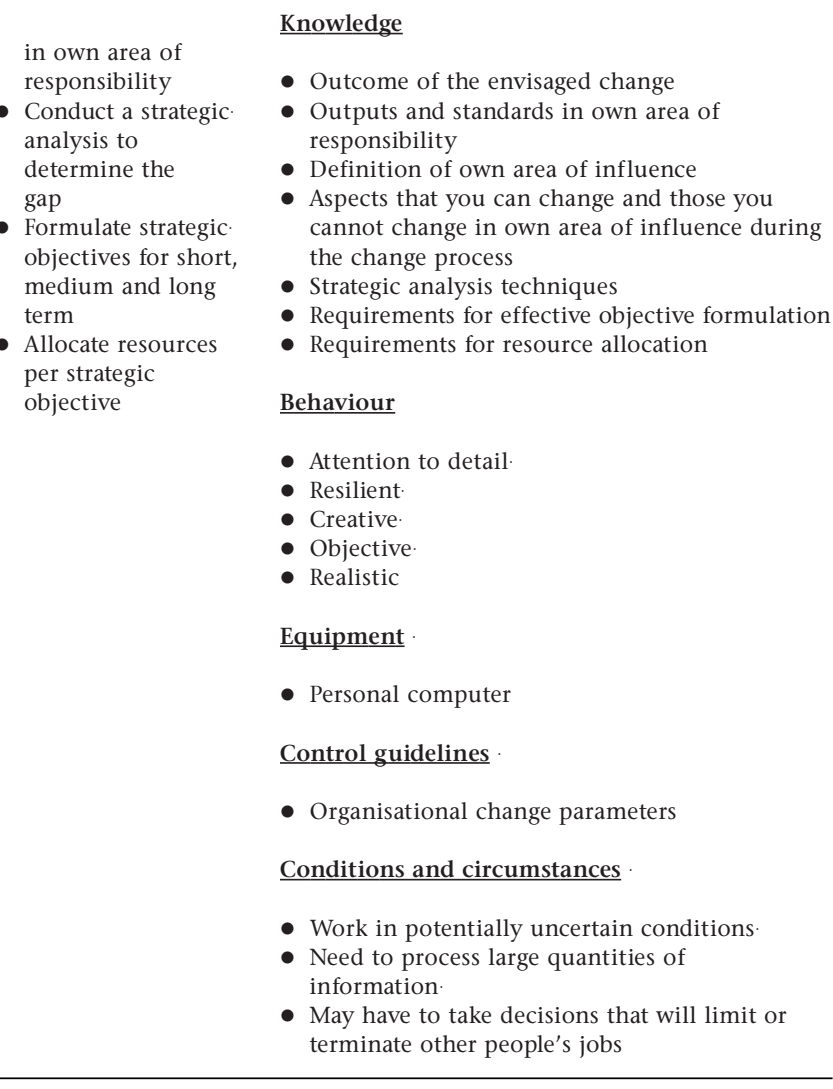

\section{Table 4}

COMPETENCIES TO FACILITATE PLANNING SESSIONS TO DETERMINE BEST-PRACTICE SOLUTIONS

Key role: Align change strategy of area of responsibility with that of the organisation

Unit of competence: Facilitate planning to determine best-practice solutions

Elements of competence

$\underline{\text { Skills }}$

- Formulate the scope of the change (problem statement)

- Confirm accuracy of problem statement with internal/external client

- Analyse the problem statement

- Determine all the elements that should be addressed to solve the problem

- Compile a suitable task team to take part in the problem solving process

- Facilitate best practice solutions for each element of the problem statement

- Draft a contingency plan for each element of the problem.

- Draft a project plan to phase in best practice solutions

- Schedule activities.

- Formulate performance standards for each deliverable

- Allocate responsibilities.

\author{
- Communicate \\ standards and \\ deadlines to the \\ people responsible. \\ - Allocate resources \\ Equipment \\ - Presentation media \\ Conditions and circumstances \\ - Need to take responsibility for decisions. \\ - Deal with diverse people \\ - Deal with conflict
}

Note: The group activities are aimed at achieving a high quality and high ownership solution

The second key role is to ensure a personal readiness for change. The unit of competence required is to prepare themselves for change, as outlined in Table 5 .

TABLE 5

COMPETENCIES TO PREPARE FOR CHANGE

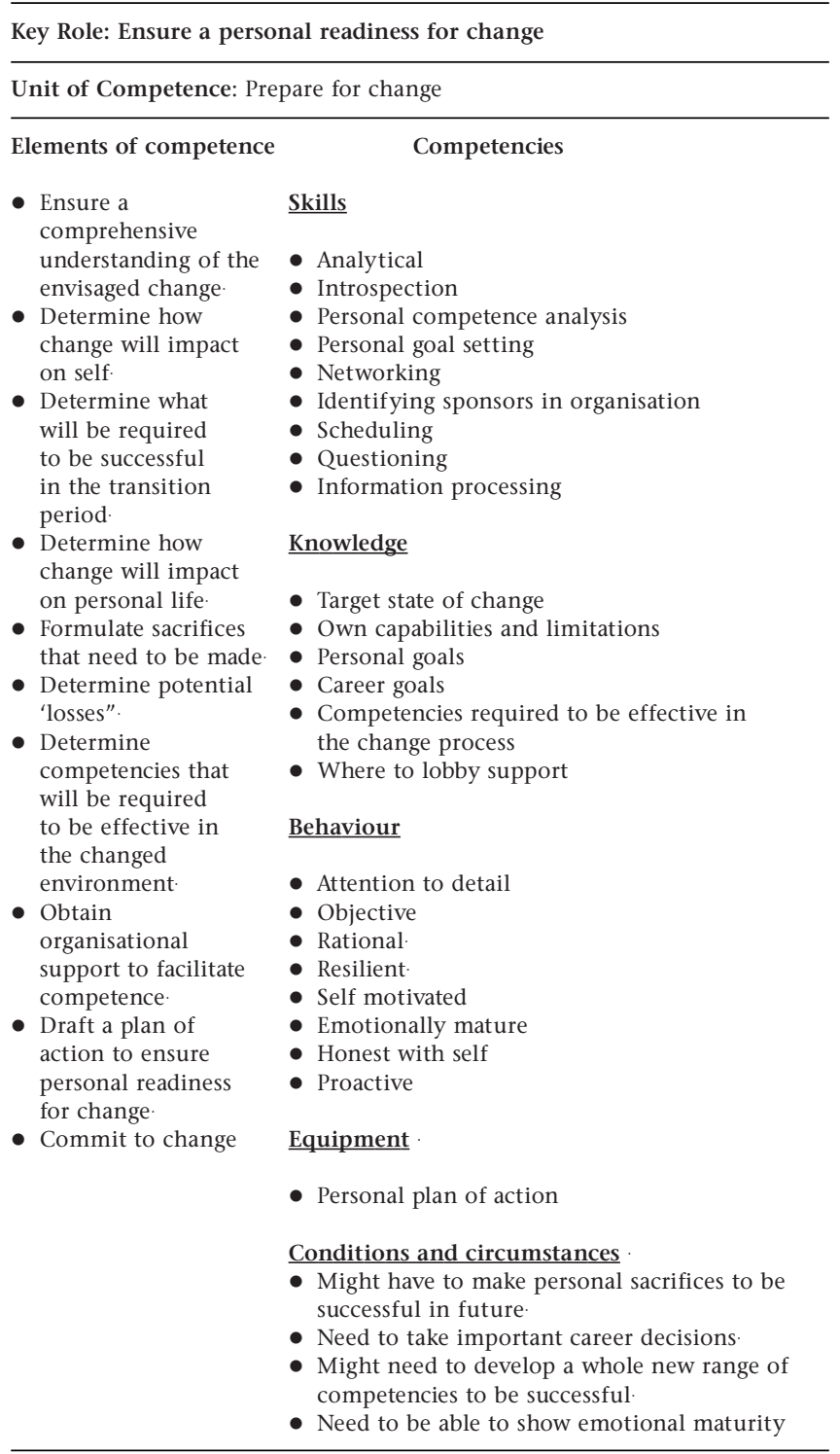

The third key role is to minimise resistance to change. The units of competence required are listed as follows:

- Conduct an audit of individual strengths and weaknesses of team members by involving them in the process.

- Compile individual communication strategies.

- Compile team communication strategies.

- Conduct individual information sessions.

- Compile individual development plans.

- Facilitate development of team members.

- Agree on a code of conduct governing behaviour during change. 
These are reflected in Tables $6-12$.

TABLE 6

COMPETENCIES TO CONDUCT AN AUDIT OF INDIVIDUAL STRENGTHS AND WEAKNESSES OF TEAM MEMBERS BY INVOLVING THEM IN THE PROCESS

\section{Key Role: Minimise resistance to change}

Unit of Competence: Conduct an audit of individual strengths and weaknesses of team members by involving them in the process

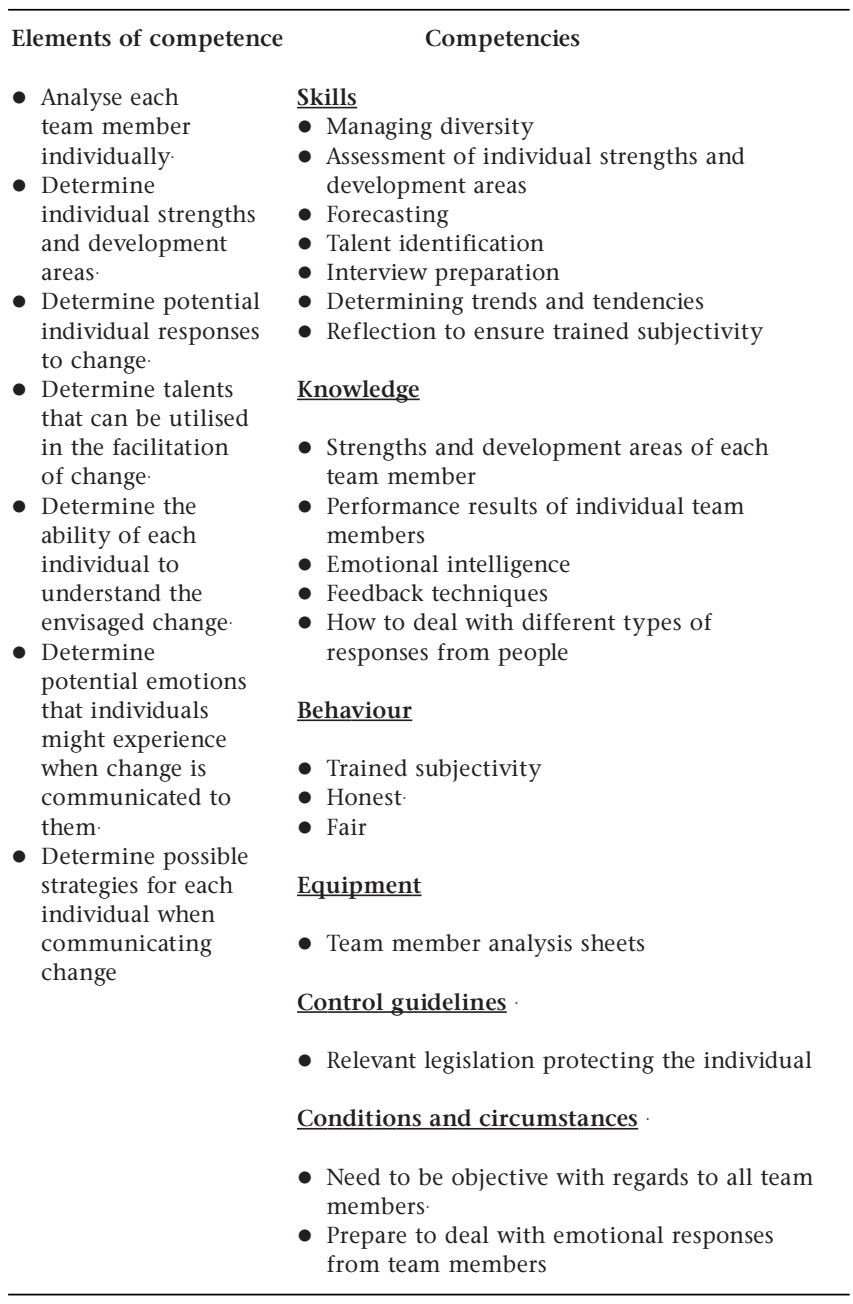

TABLE 7

COMPETENCIES TO COMPILE INDIVIDUAL COMMUNICATION STRATEGIES

Key Role: Minimise resistance to change

Unit of Competence: Compile individual communication strategies

Elements of competence

Competencies

- Consider the profiles of each individual.

- Determine the impact that the change could have on each individual.

- Consider strength and development areas

- Consider the potential emotions that individuals might experience

- Determine a $\underline{\text { Skills }}$

- Analytical

- Impact analysis

- Developing interview approach strategies

- Questioning

- Determining trends and tendencies

Knowledge

- Strengths and development areas of each team member

- Personal circumstances of individual team members

- Personality traits of team members

- Approach strategies for effective feedback individualised strategy for each person to ensure an understanding of the envisaged change

- Formulate a structure of questions per individual to ensure that each individual discovers the outcomes of the envisaged change

- Compile a logbook to document suggestions and recommendations to ensure successful change

- Need to be willing to listen and deal with people's personal circumstances

- Need to take firm decisions that can influence a person's career

TABLE 8

COMPETENCIES TO COMPLETE TEAM COMMUNICATION STRATEGIES

Key Role: Minimise resistance to change

Unit of Competence: Compile team communication strategies

Elements of competence

Competencies

- Determine the message that should

be conveyed to

the team

- Predict potential responses to the information

- Prepare answers for potential

concerns or questions

- Determine a best strategy to

communicate the message to ensure optimum impact

\section{$\underline{\text { Skills }}$}

- Analytical

- Questioning

- Forecasting

- Determining trends and tendencies

- Communicating with teams

- Facilitation of team dynamics

Knowledge

- Strengths and development areas of each team membe

- Strong personalities in the team

- Potential responses from dominating members.

- Personality traits of team members

- Approach strategies for effective feedback

- Emotional intelligence

- Group problem solving and decisionmaking strategies

Behaviour

- Objective

- Fair

- Attention to detail

- Open and honest

Equipment

- Presentation media

Control guidelines

- Relevant legislation protecting the rights of individuals

\section{Conditions and circumstances}

- Need to be able to deal with group conflict

- Need to facilitate group sessions with diverse people

Note: The need might arise in teams to obtain information relating to the change in the organisation. This will require of the first-line manager to be able to also be competent in communicating to groups or teams. 
TABLE 9

COMPETENCIES TO CONDUCT INDIVIDUAL INFORMATION SESSIONS

Key Role: Minimise resistance to change

Unit of Competence: Conduct individual information sessions

Elements of competence .

Competencies

strategy per person

- Schedule the

information session

- Determine existing

levels of

understanding of

the envisaged

change

- Ask questions to tes their understanding of the change

- Provide information as required per individual.

- Encourage individuals to explore the impact of the change on themselves.

- Determine if they have solutions or suggestions to address their concerns.

- Facilitate problem solving sessions per individual to agree on solutions to concerns to express their concerns and emotions

- Demonstrate empathy and understanding

- Agree to plans of action

- Interviewing

- Questioning

- Empathetic listening

- Communication in English

Communicating with an interpreter

(if required)

- Analytical

- Determining trends and tendencies

- Conflict handling

- Problem solving

- Dealing with emotions

- Obtaining commitment from people

- Coaching

- Individual leadership

Knowledge

- Individual strengths and development areas.

- Personal circumstances of individuals

- The envisaged change process

- Questioning techniques

- Emotional intelligence

- Typical behaviour of people when confronted with change

Behaviour

- Assertive

- Objective

- Firm.

- Fair

- Honest.

- Patient.

- Empathy
- Prepare the identified Skills

- Allow individuals

- Scheduling.

Equipment

- Prepared personal files per individual

Control guidelines

- Legislation protecting the rights of individuals

Conditions and circumstances

- Deal with people who are experiencing their emotions.

- Give negative feedback to people

- Give positive feedback to people

- Deal with conflict on a one-on-one basis

- Deal with stubborn people

- Deal with diverse people

TABLE 10

COMPETENCIES TO COMPILE INDIVIDUAL PERSONAL DEVELOPMENT PLANS

Key Role: Minimise resistance to change

Unit of Competence: Compile individual personal development plans

Elements of competence

Competencies

- Compare requirements $\underline{\text { Skills }}$

of existing roles with

that of new roles after $\bullet$ Interviewing

the change process

- Determine potentia competencies that

should be addressed

to ensure individual

Assess individual competence

- Identification of competencies to be able to perform required tasks

- Formulation of learning and development contracts

is ready to deal with $\bullet$ Questioning envisaged change.

- Facilitate individual discussions with team members.

- Agree on best practice solutions to address competencies

- Formulate learning and development contracts.

- Agree to a plan of action

- Obtain commitment

- Analytica

- Determining trends and tendencies in development needs of team members

- Obtaining commitment from people

Knowledge

- The structure of tasks in the changed environment.

- Competencies required to be effective

- Individual levels of competence.

- Options for development

Behaviour

- Development oriented

- Assertive

- Fair

- Objective

Equipment

- Learning and development contracts

Control guidelines

- Relevant company policies and procedures.

- Relevant legislation

Conditions and circumstances

- Deal with stubborn people

- Deal with diverse people

TABLE 11

COMPETENCIES TO FACILITATE DEVELOPMENT OF TEAM MEMBERS

Key Role: Minimise resistance to change

Unit of Competence: Facilitate development of team members

Elements of competence

Competencies

- Communicate the training and development needs of team members to relevant stakeholders in the organisation

- Obtain commitment for the development process

- Agree on an implementation strategy.

kills

- Networking

- Identifying sponsors in organisation

- Scheduling

- Questioning

- Analytical.

- Determining trends and tendencies in the development needs of team members

- Obtaining commitment from people in functional departments

- Persuasion.

- Provide opportunities - Resource allocation

and support to

team members

- Team leadership

Knowledge

- Organisational structure

- People responsible for training and development

$\underline{\text { Behaviour }}$

- Development oriented

- Assertive

- Committed to team members.

- Proactive

Equipment

- Internal communication channels

Control guidelines

- Relevant company policies and procedures.

- Relevant legislation

Conditions and circumstances

- Liase across functional department

- Deal with areas outside own area of expertise

- Need to obtain commitment from people across departments 
TABLE 12

COMPETENCIES TO AGREE ON A CODE OF CONDUCT THAT WOULD GOVERN BEHAVIOUR DURING CHANGE

Key Role: Minimise resistance to change

Unit of Competence: Agree on a code of conduct governing behaviour during change

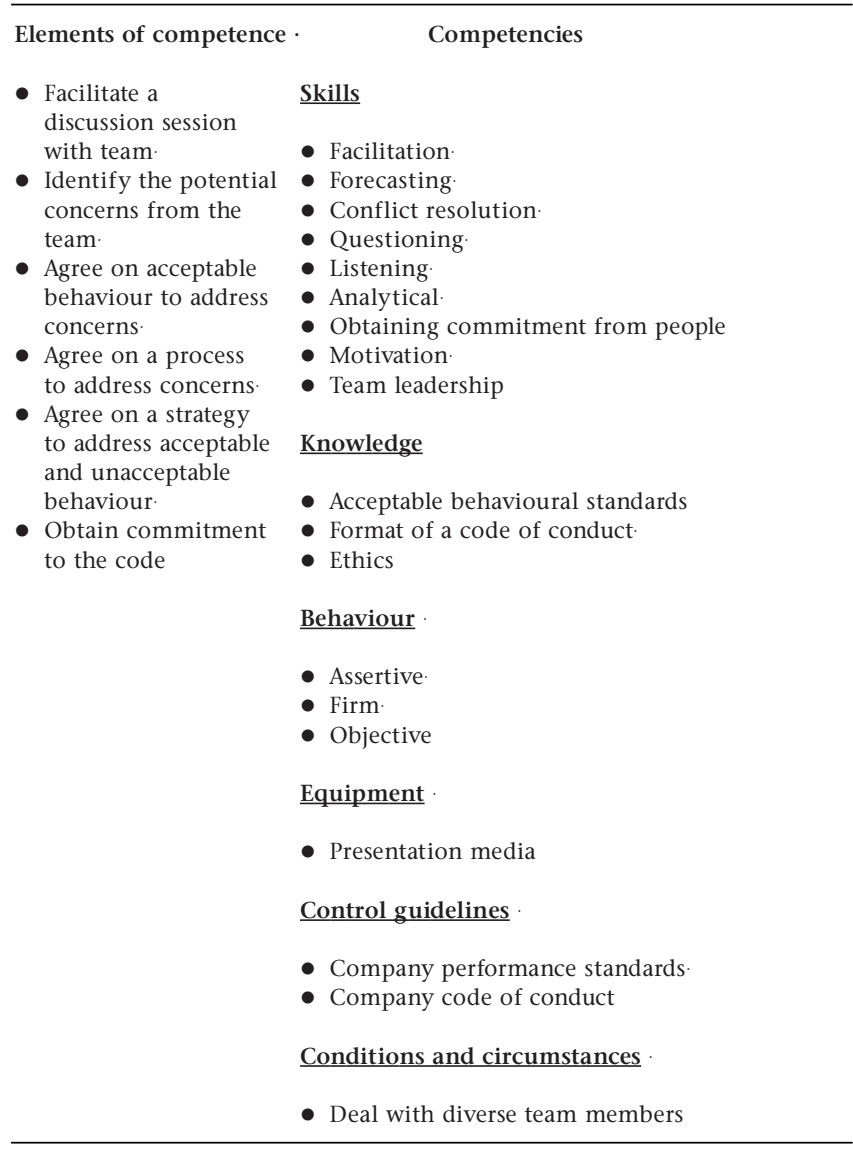

Note: A code of conduct that would govern behaviour during change will require input from the team members to ensure high ownership. This will require a competency that requires team-related activities.

The final key role is to continuously act as a catalyst for change. In order to achieve this, first-line managers should be able to:

- Understand the rationale for change.

- Develop a business case for change.

These are outlined in Tables $13-14$.

TABLE 13

COMPETENCIES TO UNDERSTAND THE RATIONALE FOR CHANGE

Key Role: Act as a continual catalyst for change

Unit of Competence: Understand the rationale for change

\section{Elements of competence}

Competencies

- Obtain information $\underline{\text { Skills }}$

regarding the

envisaged change

- Compare existing state with target state

- Determine the change in behaviour process, systems and/or technology in the organisation

- Determine the

change in behaviour, - Business processes

process, systems and/ • Core business

or technology in own $\bullet$ Client requirements

area of influence

- Company systems and technology
- Ensure a $\quad-$ Own area of responsibility

understanding of

the reasons for

change

- Communicate

concerns and/or

suggestions to

immediate supervisor

and/or expert

- Ensure that

rationale for change

is understood

$\underline{\text { Behaviour }}$

- Assertive

- Attention to detail

- Objective

- Proactive

Control guidelines

- Organisational change strategy document

Conditions and circumstances

- Analyse large quantities of information

- Need to communicate with senior stakeholders

TABLE 14

COMPETENCIES TO DEVELOP A BUSINESS CASE FOR BOTOOM-UP CHANGE

Key Role: Act as a continual catalyst for change

Unit of Competence: Develop a business case for bottom-up change

Elements of Competence Competencies

- Facilitate regular meetings with team members and customers.

- Identify areas for potential improvement

- Facilitate problem solving sessions with team members

- Obtain commitment

from team members.

- Document suggestions - Analyse information to motivate new changes

- Determine advantages - Obtaining commitment from seniors to the organisation

- Build a business case Knowledge for change

- Present to relevant decision-makers in the organisation

- Organisational processes, systems and technology and behaviour

- Client requirements

- Market demands

- Market trends

- Group problem solving and decisionmaking techniques

- Group dynamics

$\underline{\text { Behaviour }}$

- Attention to detail

- Accurate

- Creative

- Assertive.

- Proactive

Equipment

- Presentation media

Control guidelines

- Core business of organisation

- Existing company strategies

Conditions and circumstances

- Suggest solutions to key stakeholders

- Need to be able to think on levels more complex than existing level in the organisation

Note: Bottom-up change implies that input comes from the team. This requires teamrelated competencies.

In summary, the skills, knowledge and behaviour listed below would be used most frequently in managing resistance to change and should thus be priorities in developing first-line managers. 
TABLE 15

SKILLS, KNOWLEDGE AND BEHAVIOUR THAT APPEAR MOST FREQUENTLY IN THE FUNCTIONAL ANALYSIS

\begin{tabular}{|c|c|c|}
\hline Skills & Knowledge & Behaviour \\
\hline $\begin{array}{ll}\checkmark & \text { Analytical } \\
\checkmark & \text { Decision-making } \\
\checkmark & \text { Determining trends } \\
& \text { and tendencies } \\
\checkmark & \text { Effective } \\
& \text { communication } \\
\checkmark & \text { Effective listening } \\
\checkmark & \text { Facilitation } \\
\checkmark & \text { Interviewing } \\
\checkmark & \text { Networking } \\
\checkmark & \text { Motivation } \\
\checkmark & \text { Questioning } \\
\checkmark & \text { Obtaining } \\
& \text { commitment from } \\
& \text { people } \\
\checkmark & \text { Persuasion } \\
\checkmark & \text { Problem solving } \\
\checkmark & \text { Scheduling } \\
\checkmark & \text { Team leadership }\end{array}$ & $\begin{array}{l}\checkmark \text { Approach strategies } \\
\text { for providing } \\
\text { feedback } \\
\checkmark \text { Client needs and } \\
\text { requirements } \\
\checkmark \text { Emotional } \\
\text { intelligence } \\
\checkmark \text { Group decision- } \\
\text { making techniques } \\
\checkmark \text { Group problem } \\
\text { solving techniques } \\
\checkmark \text { Personal } \\
\text { circumstances of } \\
\text { team members } \\
\checkmark \text { Questioning } \\
\text { techniques } \\
\checkmark \text { Strengths and } \\
\text { limitations of } \\
\text { individual team } \\
\text { members } \\
\checkmark \text { Where to lobby for } \\
\text { support in the } \\
\text { organisation }\end{array}$ & $\begin{array}{ll}\checkmark & \text { Assertiveness } \\
\checkmark & \text { Attention to } \\
& \text { detail } \\
\checkmark & \text { Fair } \\
\checkmark & \text { Firm } \\
\checkmark & \text { Open and honest } \\
\checkmark & \text { Patient } \\
\checkmark & \text { Proactive } \\
\checkmark & \text { Resilient } \\
\checkmark & \text { Trained subjectivity }\end{array}$ \\
\hline
\end{tabular}

\section{CONCLUSION}

In the challenge to ensure the effective management of resistance to change, first-line managers will have to make use of a combination of team as well as individually focused interventions in their areas of responsibility. In the process they will have to focus on both the cognitive as well as emotional levels of employees to obtain commitment on an individual and team level. Technical competence is therefore not sufficient to facilitate effective change and firstline managers need to develop their understanding of emotional intelligence and reactions of people when confronted with change.

Furthermore, first-line managers and their teams can play an important role in identifying opportunities for change in order to improve product and service delivery. Teams will own change initiatives with potentially greater commitment and minimal resistance. First-line managers can therefore contribute to organisational effectiveness and customer satisfaction by persuading decision-makers to implement suggestions from operative employee level.

The competencies identified in this study can used to develop outcomes-based interventions to enable first-line managers across various industries to deal with resistance to change within their unique conditions and circumstances. In addition to the developmental value however, an important contribution of the study is to highlight the invaluable role of the first-line manager in implementing effective change interventions.

\section{REFERENCES}

Appelbaum, S.H., St-Pierre, N., \& Glavas, W. (1998). Strategic organisational change: The role of leadership, learning, motivation and productivity. Management Decision, 36 (5), pp. $289-301$.

Bechtel, R.L., \& Squires, J.K. (2001). Tools and techniques to facilitate change. Industrial and Commercial Training, 33 (7), pp. $249-254$.

Buckingham, M. \& Coffman, C. First, break all the rules. What the world's greatest managers do differently. London: Simon \& Schuster Business Books.
Burdett, J.O. (1999). Leadership in change and the wisdom of a gentleman. Participation \& Empowerment: An international journal, 7 (1), pp. 5 - 14.

Clarke, M., \& Meldrum, M. (1999). Creating change from below: Early lessons for agents of change. The Leadership and Organization Development Journal, 20 (2), pp. 70 - 80.

Claxton, G. (1999). Wise up: The challenge of life-long learning. London: Bloomsbury.

Coker, C. (2000). Resistance to change and obstacles that can be overcome. Business Journal: Serving Jacksonville \& Northeast Florida, 15 (17), p.24.

Corporate Executive Board, (2001a). Change management models and business applications. Corporate Leadership Council Fact Brief, pp. 1 - 20 .

Corporate Executive Board, (2001b). Communicating corporate change. Corporate Leadership Council Fact Brief, pp. 1 - 3.

Corporate Executive Board, (2001c). Preparing for corporate change. Corporate Leadership Council Fact Brief, pp. 1 - 3.

De Jager, P. (2001). Resistance to change: A new view of an old problem. Futurist, 35 (3), pp. 24 -27.

Eby, L.T., Adams, D.M., Russel, J.E.A., \& Gaby, S.H. (2000). Perceptions of organisational readiness for change: Factors related to employees' reactions to the implementation of team-based selling. Human Relations, 53 (3), pp. 419 - 439.

Fletcher, S. (1997). Designing Competence-Based Training. London: Kogan Page.

French, E., \& Delahaye, B. (1996). Individual change transition: Moving in circles can be good for you. Leadership \& Organisational Development Journal, 17 (7), pp. $22-28$.

Folger, R., \& Skarlicki, D.P. (1999). Unfairness and resistance to change: Hardship as mistreatment. Journal of Organizational Change Management, 12 (1), pp. 35 -50.

Garavan, T.N., Barnicle, B., \& O'Suilleabhain, F. (1999). Management development: Contemporary trends, issues and strategies. Journal of European Industrial Training, 23 (4/5), pp. $191-207$.

George, J.M., \& Jones, G.R. (2001). Towards a process model of individual change in organisations. Human Relations, 54 (4), pp. $419-439$.

Goleman, D. (1996). Emotional Intelligence. London: Bloomsbury.

Gratton, L. (2000). Living strategy: Putting people at the heart of corporate success. London: Prentice Hall.

Hoopes, L.L., \& Hale, S.L. (1999). Facing the challenge of change. CPCU Journal, 55 (2), pp. 90 - 103.

Hudson, M.P. (1999). Conflict and stress in times of change. Library Management, 20 (1), pp. 35 - 38.

Kets de Vries, M.F.R. (2002). Can CEO's change? Yes but only if they want to. Paper presented to the INSEAD Alumni at a breakfast meeting at the Grace Hotel on 4 July 2002.

Kinnear, C., \& Roodt, G. (1998). The development of an instrument for measuring organisational inertia. Journal of Industrial Psychology, 24 (2), pp. $44-54$.

Kotter, J.P. (1996). Leading Change. Boston: HBS Press.

Kotter, J.P., \& Cohen, D.S. (2002). The Heart of Change. Boston: HBS Press.

Lewis, B. (1998). Managing change is not enough: You must create a culture that embraces it. InfoWorld, 20 (45), p. 105.

Lindsay, P.R., \& Stuart, R. (1997). Reconstruing competence. Journal of European Industrial Training, 21 (9), pp. 326 - 332.

Mabin, V.J., Forgeson, S., \& Green, L. (2001). Harnessing resistance: Using the theory of constraints to assist change management. Journal of European Industrial Training, 25 (2/3/4), pp. $168-191$.

Mariotti, J. (1998). The challenge of change. Industry Week, 247 (7), p. 140.

Maurer, R. (2000). What blocks support? Journal for Quality and Participation, 23 (3), p. 47.

Moran, J.W., \& Brightman, B.K. (2001). Leading organisational change. Career Development International, 6 (2), pp. 111 - 118.

National Examining Board for Supervisors and Management (NEBS \& M). 1998. NVQ/SVQ in Management Level 3. London: Crown. 
Pheng, L.S. (1999). Towards managerial efficacy: Back to 2,000year-old guiding principles. The Learning Organisation, 6 (3), pp. $121-131$.

Rampersad, H. (2001). 75 Painful questions about your customer satisfaction. The TQM Magazine, 13 (5), pp. 341 - 347.

Seely, C. (2000). Change Management: A base for knowledgesharing. Knowledge Management, 3 (4), pp. 24 - 29.

Steiner, C. (2001). A role for individuality and mystery in "managing" change. Journal of Organizational Change Management, 14 (2), pp. 150 - 167.
Walker, C. (1999). Making change work for you. Women in business, 51 (4), pp. 51 - 53.

Weber, P.S., \& Weber, J.E. (2001). Changes in employee perceptions during organisational change. Leadership \& Organisational Development Journal, 22 (6), pp. 291 - 300.

Zeffane, R. (1996). Dynamics of strategic change: Critical issues in fostering positive organizational change. Leadership \& Organisational Development Journal, 17 (7), pp. $36-43$. 